\title{
THE MULTIMODAL CARRIER'S LIABILITY FOR NON-LOCALIZED LOSS
}

DATA PRZESŁANIA: 15.09.2016| DATA AKCEPTACJI: 6.12.2016|JEL CODES: K12, K22

\section{Daniel Dąbrowski}

Wydział Zarządzania i Ekonomiki Usług, Uniwersytet Szczeciński

e-mail: daniel.dabrowski@wzieu.pl the loss of goods when the loss cannot be attributed to the specific stage of multimodal carriage. The author points out the situations in which the regime of the carrier's liability is directly defined by the domestic or international transport law. However there are many situations when finding the proper regime is more difficult. The author is of the opinion that a multimodal carriage contract is of a mixed nature. The methods of ascertaining legal effects of mixed contracts can be helpful in determination of legal effects of a multimodal carriage contract including rules of the carrier's liability.

multimodal transport, multimodal carriage contract, non-localized loss, non-localized damage, carrier's liability, mixed contracts;

\section{INTRODUCTION}

One of the fundamental problems of multimodal transport of goods is the carrier's liability for the loss ${ }^{1}$ when it is impossible to determine at which stage of transport the loss of or damage to the goods occurred. Past attempts to create an international convention regulating multimodal transport of goods were undertaken mainly to solve this problem. The convention concerning the carrier's liability under the multimodal carriage contract has not been being in force to date and, as it may be assumed, it will not take place soon. In some countries the lack of fitting international regulations stimulated the establishment of national rules governing the multimodal

1 The term "loss" used in this context refers to the actual loss of the goods as well as to damage to the cargo or even just to its delay. See Hoeks (2010), p. 17. 
carriage contract. Such rules were not introduced into the Polish legal system at least in relation to international transport. The purpose of this article is to answer the question, how the problem of the carrier's liability for non-localized loss should be addressed in Poland in light of national and international regulations.

\section{THE PROBLEM OF NON-LOCALIZED LOSS}

A characteristic feature of multimodal carriage of goods is that a multimodal carrier (also known as a multimodal transport operator (MTOs)) uses at least two different modes of transport. Such transport is performed on the basis of a single multimodal carriage contract, which provides such a manner of carriage performance (Hoeks, 2010, p. 6; Kwaśniewski, 1989, p. 15-16). A great deal of multimodal transport is performed in containers. The container can speed up the process of transport, makes handling easier and provides protection for the goods transported. However, the usage of a container excludes the possibility of observation of the state of goods contained therein. Therefore, any damage can be discovered only when opening the container (usually by the recipient). In such a situation it is very difficult to attribute the loss to the relevant transport stages. This situation is briefly referred as non-localized loss or unlocalized (unattributed) loss. This term does not refer to a specific type of loss (damage) but means that it is impossible to ascertain where (i.e. during which stage of transport) the loss occurred.

The problem of non-localized loss is not limited to multimodal transport. It manifests itself, with even greater intensity, when the sender concludes (directly or via a freight forwarder) several separate contracts with carriers, and each of the carriers transports a container during a certain stage of transport. In case of multimodal transport at least, the claimant knows against whom to make a claim because the contract was concluded with one entity (a multimodal carrier) and only the liability regime is dubious. When several contracts are concluded, the claimant is denied the opportunity to pursue the claim. The burden of proof that the loss or damage had occurred during a particular stage of the transport is borne by the claimant. Inability to prove it excludes the possibility of seeking the compensation (Kwaśniewski, 1989, p. 22).

The international regulation on the multimodal carriage contract was to solve, among others, the problem of non-localized loss. One way to achieve this goal was the attempt to introduce the so-called uniform liability system. Within this system the same set of rules applies irrespective of the stage of transport during which loss, damage or delays occur (Hoeks, 2010, p. 27-29; Kwaśniewski, 1989, p. 21-25, 53). Such a system is adopted, among others, by the United Nations Convention on International Multimodal Transport of Goods signed in Geneva on 24 May 1980 (MT Convention), although the unification of the carrier's liability under the convention was not complete $^{2}$. Only the basis of the carrier's liability, and issues concerning the burden of proof, have been fully harmonized. With regard to the scope of the carrier's liability, the MT Convention allows the carrier to refer to the limitation of the liability provided for in the unimodal convention, which applies to the stage of transport during which loss, damage or delays occur. However, when it is impossible to determine on which stage of transport the loss, damage or delay occurs, the limitation of liability laid down in the MT Convention applies, wherein the limits of the carrier's liability vary depending on whether the contract provides for carriage by sea or inland waterway.

The MT Convention has not entered into force due to an insufficient number of ratifications. The failure of the MT Convention calls into question the practicality of introducing a uniform

2 More on this convention see e.g. Glass (2013), p. 314-337; Hoeks (2010), p. 20-22; Kwaśniewski (1989), p. 128 et seq. 
liability system of multimodal carrier. The critics of the said system pointed out to the inevitable collision between the convention introducing an uniform liability system and unimodal conventions (Glass, 2013, p. 335-336; Hoeks, 2010, p. 26-27). Therefore, further work on the international arena focused on regulation of a separate liability regime for multimodal carriage contract which applies only in case of non-localized loss. This concept, known as the modified network system or the modified system, has been adopted, among others, by the United Nations Convention on Contracts for the International Carriage of Goods Wholly or Partly by Sea, signed at Rotterdam on 23 September 2009 (Rotterdam Rules) ${ }^{3}$. The regime of the Rotterdam Rules applies to contracts of carriage which provide for carriage only by sea, as well as to contracts of carriage which provide carriage by sea, and by other modes of transport in addition to the sea carriage. In case of non-localized loss, the carrier's liability is governed by the Rotterdam Rules. However if loss of or damage to the goods, or an event or circumstances causing a delay in their delivery occurs solely before their loading onto the ship. or solely after their discharge from the ship, then the regulation of another international instrument (i.e. the unimodal convention) providing for the carrier's liability, limitation of liability or time for suit applies (art. 26 RR).

In those countries which have introduced special regulations for multimodal transport by national legislation, they implement a similar concept, although there are differences between the solutions adopted in these countries. For example, in Germany a multimodal carriage contract is regulated by the provisions of the German Commercial Code ( $\$ 452 \mathrm{HGB}$ ). However, if it is possible to determine that the loss of or damage to the goods or event causing the delay has occurred at a specific stage of the transport, then the carrier's liability is governed by the provision of the relevant act which would have been applied to the said specific stage of transport (Article 452a item $1 \mathrm{HGB}$ ). A similar solution was adopted in Spanish law (article 68 section 3 of the Spanish Act of 11 November 2009 on the contract of carriage of goods by land) and in some Latin American countries ${ }^{4}$. In Dutch law, as a general rule, the regime appropriate to the specific stage of transport applies to each stage of a multimodal transport (article 8:41 BW). If the multimodal carrier is liable for the damages resulting from damage, total or partial loss, delay or any other damaging fact, and if it has not been ascertained where the fact leading thereto has arisen, the carrier's liability is determined according to the regime which applies to that stage, or to those stages in the transport where this fact may have arisen, and from which the highest amount of damages results (article 8:43 BW).

\section{THE LIABILITY FOR NON-LOCALIZED LOSS IN POLISH LAW}

\section{Cases governed directly by domestic and international law}

There is no problem with non-localized loss when the contract for multimodal transport provides for the domestic carriage and the itinerary does not contain sea or air stage. The Act of 15 November 1984 on Transport Law $^{5}$ applies to such a contract. The scope of application of the said Act was defined in the provision of Article 1 section 1, according to which, "The Act

\footnotetext{
3 The Rotterdam Rules are not in force yet. To 22 September 201626 countries signed the convention and only 3 countries Spain, Togo and Congo have ratified the Rotterdam Rules. The article 94 section 1 of the convention states as follows: "This Convention enters into force on the first day of the month following the expiration of one year after the date of deposit of the twentieth instrument of ratification, acceptance, approval or accession".

4 For more information see e.g. Report prepared by the UNCTAD secretariat (UNCTAD/SDTE/TLB/2) (http:// unctad.org/en/Pages/DTL/TTL/Legal/Carriage-of-Goods.aspx).

5 Consolidated text: Journal of Acts 2015, item 915.
} 
regulates the transport of persons and things performed for consideration under contract by authorized carriers, with the exception of maritime, air and horse-drawn transport". The multimodal transport is not expressly mentioned, but due to the lack of exclusion, there is no doubt that the Act applies to them (Ambrożuk, Dąbrowski, Wesołowski, 2014, p. 20). The Transport Law regulates, therefore, the conclusion and execution of the contract of multimodal carriage of goods, the issues related to the transport documents, and in particular the carrier's liability for loss or damage to the goods and the delay in the carriage. Due to the unified rules in the Act for the liability of carriers of different modes of transport, the problem of non-localized loss does not exist. In case of loss of or damage to the goods during the multimodal transport, the carrier is liable in accordance with the rules laid down in Article 65 et seq., of the Transport Act irrespective of during which stage of transport the loss occurred. The claimant is not obliged to prove during which stage of transport the loss occurred, and need only prove that it occurred between the time when the carrier takes possesion the goods and the time of delivery (Ambrożuk et al., 2014, p. 283). This also applies when the multimodal carriage contract was concluded under conditions laid down in Article 6 section 1 Transport Law, i.e., when several carriers of different modes of transport, (being the subject to the Transport Law), undertook to carry goods under the single contract. The claimant also in this case is not obliged to prove where the loss or damage has occurred, and he may pursue a claim against each of the carriers engaged in the carriage, whose liability is joint and several. The issue of non-localized loss is significant from the point of view of recourse between carriers. According to the Article 6 section 3 of Transport Law, "A carrier who has paid compensation shall have a right of recourse against the carrier who is responsible for the circumstances which resulted in damage. If these circumstances may not be determined each carrier is liable in proportion to the share of the payment for the carriage which is due to him; the carrier who proves that the damage has not occurred during the stage of the transport which he performed shall be released from all liability".

The unified regime of the carrier's liability also applies to the multimodal contract of carriage which includes carriage by road or inland waterway in internal transport as a supplement to

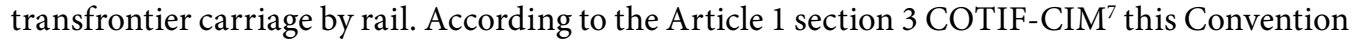
applies to such a contract despite providing transport by modes of transport other than rail. This also applies to an international carriage being the subject of a single contract of carriage which includes carriage by sea or transfrontier carriage by inland waterway as a supplement to carriage by rail, but only if the carriage by sea or inland waterway is performed on services included in the list of services announced by the Intergovernmental Organisation for International Carriage by Rail (OTIF). In both cases the problem of non-localized loss does not occur, because the carrier's liability shall be governed by the COTIF-CIM, regardless of whether the place of the occurrence of loss is known.

If the multimodal carriage contract involves a sea leg, then the legal situation of the parties depends on whether a through bill of lading has been issued by the carrier. If a through bill of lading has been issued, then Articles 138 and 139 of the Act of 18 September 2001 the Maritime Code $^{8}$ apply. According to the Article 138 section 1 of Maritime Code "Subject to the exceptions provided for by statutory law, the provisions concerning the bill of lading shall apply accordingly

\footnotetext{
6 More on this subject see Ambrożuk, Dąbrowski, Wesołowski (2014), p. 54-55.

The Convention concerning International Carriage by Rail of 9 may 1980 as amended by the Protocol of Modification of 3 June 1999 (Vilnius) - Appendix B (CIM). Consolidated text: Journal of Acts 2007, No. 100, item 674 as amended.

8 Consolidated text: Journal of Acts 2016, item 66.
} 
to the through bill of lading issued by the maritime carrier who undertakes the carriage which is to be performed on the part of the route by another carrier (by sea, inland water, land or air)". Article 138 section 2 of the Maritime Code states that "to these stages of the carriage which are not the sea stage, the regime applicable to a particular mode of transport applies. If it is not possible to ascertain during which stage of the transport the event occurred, the provisions of the Maritime Code apply to the examination of effects thereof". The provision does not specify the kind of "event", but there is no doubt that it refers to the events resulting in loss of or damage to the goods, or the delay in carriage. Without a doubt, therefore it relates to non-localized loss. The maritime carrier is liable for this kind of loss in accordance with the rules of the Maritime Code. This principle is not modified by the provisions of Article 139 the Maritime Code. According to the Article $139 \$ 1$ of the Maritime Code "A carrier who issued the through bill of lading is responsible for the due performance of the obligations of the carrier along the route covered by the bill of lading, until the release of the goods to the authorized consignee. Each of the other carriers is responsible for the performance of these obligations during the stage of the transport handled by him jointly and severally with the carrier who issued the through bill of lading". If it is possible to ascertain during which stage of transport the loss or damage occurred, the claimant may therefore claims compensation from both the maritime carrier, as well as the carrier who handled the stage of the transport during which the loss or damage occurred. The liability of each carrier is governed by the law applicable to the stage during which the loss or damage occurred. The Article 139 section 2 Maritime Code allows limitation of the liability to the carrier who issued the through bill of lading exclusively to "the stage of transport handled by him". In this case, if a localized loss occurs, the claimant is entitled to pursue a claim only against the carrier who performed the stage of transport during which the loss has occurred. This limitation of liability of the carrier who issued the through bill of lading does not affect his responsibility if it is impossible to ascertain in which stage of transport the loss has occurred. In case of non-localized loss, the claimant may pursue a claim against the carrier who issued a through bill of lading.

Those rules of the Maritime Code are applicable both in a situation in which the sea transport is domestic, as well as when it is international (of course if the Polish law applies). The nature (domestic or international) of the other stages of transport is also not important. So if the through bill of lading was issued covering the carriage by sea and then the international carriage by road, then in case of non-localized loss the carrier's liability is governed by the Maritime Code. It does not conflict with the binding nature of provisions of the CMR Convention, which would apply in case of ascertaining that the loss or damage occurred during the road stage of transport. Since it is not possible to ascertain where the loss occurred, there are no prerequisites to apply the CMR Convention.

Liability for non-localized loss is also regulated - albeit to a limited extent - in the case of carriage performed partly by air, and partly by any other mode of carriage. However, this applies only to the situation in which the carriage by other mode of transport is supplementary to the air carriage, i.e., it is performed for the purpose of loading, delivery or transhipment. According to the Article 18 section 4 sentence 1 and 2 of the Montreal Convention", "The period of the carriage by air does not extend to any carriage by land, sea or inland waterways, performed outside an airport. If, however, such carriage takes place in the performance of a contract for carriage by air, for the purpose of loading, delivery or transhipment, any damage is presumed, subject to proof to the contrary, to have been the result of an event which took place during the carriage by air".

9 Convention for the Unification of Certain Rules for International Carriage by Air, signed at Montreal on 28 May 1999. Consolidated tex: Journal of Acts 2007, No 37, item 235. 
Also in this case, it does not matter if air carriage is domestic or international. Pursuant to Article 208 section 2 of the Act of 3 July 2002 Aviation Law ${ }^{10}$ the provisions of the Montreal Convention on the carrier's liability shall also apply to domestic air carriage.

\section{Searching for the applicable regime - Cases which are not clearly regulated}

An important number of multimodal carriages are not covered by the provisions discussed above. They concern in particular contracts involving air carriage, and, road or rail carriage (domestic or international) if such road or rail carriage is not supplementary to the air carriage. The same applies to multimodal carriage performed partly by sea if the through bill of lading is not issued, and road-rail carriage if the road or rail carriage is international. In most of these cases, the problem of determining the applicable regime of the carrier's liability exists even if the place of occurrence of the loss or damage is known. That is because of doubts about the application of unimodal conventions to relevant stages of the multimodal carriage. Some authors are of the opinion that the regimes of unimodal conventions should not be applied to multimodal carriage contract at all. Others stand for application of the unimodal conventions to separate stages of multimodal carriage. The judgements in different countries are divergent and the problem is still unsolved ${ }^{11}$.

It is clear that the person who suffered loss or damage should have the opportunity to claim for compensation from the multimodal carrier in case of localized as well, as non-localized loss. Ascertaining the proper regime of the carrier's liability is not as clear. This issue is however essential for both parties. The regimes of the carrier's liability in particular modes of transport in domestic and international law differ significantly. The differences concern among others the bases of liability, array of exonerations, the time bar on protest and litigation, jurisdiction, rules on carriage documentation, etc. The difference in the carrier's liability limitations is of great importance - there is no such a limitation in Polish Transport Law, while it exists in unimodal conventions, although the carrier's liability limitations differ per mode of transport ${ }^{12}$.

The starting point for solving of the problem described above must be the question of the legal nature of a multimodal carriage of goods contract. Generally speaking, the contract for carriage of goods is considered to be an independent type of contract, while the contracts for carriage by a particular means of transport are considered subtypes of this general type. Likewise, the contract for multimodal carriage of goods should be regarded as a subtype of a general type of a contract for carriage of goods. However there is one important difference: The subtypes of the contract for carriage of goods by the particular modes of transport are named contracts. In contrast, a multimodal carriage of goods contract is of a mixed nature, combining elements of two or more subtypes of the contract for carriage. Some authors are of the opinion that the multimodal carriage contract is sui generis contract ${ }^{13}$. It is beyond the scope of this article to deal with this matter. However it seems that there is no basis for a such assessment. As indicated above under a contract for multimodal carriage of goods, the carrier undertakes to perform the carriage of goods by at least two different modes of transport. It means that the performance which the carrier is obliged to effect is the combination of performances from two or more subtypes of the contract for the carriage of goods. Those who adhere to the sui generis doctrine pertaining to the multimodal contract point out that the multimodal carrier is not only obliged

10 Consolidated text: Journal of Acts 2013, item 1393 as amended.

11 See e.g. Dąbrowski (2015), p. 30-35; Hoeks (2010), p. 31-35, (2013), p. 45-64.

12 See e.g. Hoeks (2010), p. 15.

13 See e.g. Hoeks (2010), p. 75-81; Kwaśniewski (1989), p. 69-80. 
to carry the goods but also to tranship or store the goods (Hoeks, 2010, p. 75). However, these activities of the carrier may not be regarded as the characteristic performance of the contract, and they may not determine the legal nature thereof. Therefore, it seems a justified thesis that, as a general rule, the combination doctrine should be applied for the assessment of legal effects of a multimodal carriage of goods contract. It means that such a contract should be dissected into various sufficiently independent parts, and the rules of law whose requirements are met by these parts will apply (Hoeks, 2010, p. 73).

However, the combination doctrine cannot help with the problem of non-localized loss. So it is necessary to refer to other methods of assessing of mixed contracts legal effects. The most effective is a compromise method which provides for the assessment of mixed contract rules taken from several methods to take into account, as much as possible, social and economic purpose of a contract, interests and intentions of the parties etc. (Krzemiński, 2010, p. 266). In the case of multimodal carriage of goods, it is necessary to search for solutions that ensure a balance of interests. It is also important that the result of that assessment should be predictable, i.e., that parties at the time of concluding the contract can predict that in the event of non-localized loss the specific regime applies.

In the first place, for the assessment of legal effects of a contract for multimodal carriage of goods in relation to the carrier's liability for non-localized loss, application of the absorption method should be considered ${ }^{14}$. According to this method, it is necessary to search for the prevailing, key elements of a contract assuming that they absorb other elements. The most commonly used criterion is the criterion of length of each stage of transport and the aim of the stage of transport, (delivery to the sea port, the airport, transportation between airports or sea ports, etc.). Assessment in this regard should not be mechanical. Usually the sea, or air stage is longer than the road or rail stage. It does not mean, however, that the assessment of effects of non-localized loss will always be made on the basis of the provisions governing a sea or air carrier liability. The length of the stage should be the auxiliary criterion; the time and costs of each stage, and risks associated with stages should be also considered. Application of the regime of one stage to the whole contract is appropriate only when a comprehensive assessment of the contract leads to a clear conclusion about the overwhelming nature of this stage. It concerns particularly situations which are similar to those regulated in the Article 18, paragraph 4, sentence 3, of Montreal Convention.

If each stage of a carriage is equivalent, the absorption method may not be used. Then (and only then) it is reasonable to assess a multimodal carriage of goods contract effects as if it were an emancipated subtype of the contract of carriage. In Polish law, this leads to the application of the Transport Law, even if the transport is international. The provision of Article 1, section 3, of Transport Law provides that the provisions of this Act shall apply to international transport unless an international convention provides otherwise. If no international convention regulates the contracts for multimodal carriage of goods and, at the same time, it is not possible to use the unimodal convention relating to the particular segment of transport, it is necessary to apply the domestic law.

In my opinion it is not possible to apply the regime which is most favourable to a claimant ${ }^{15}$, or the regime that would allow a claimant to obtain the highest compensation. The application of such a regime would require a clear legal basis. There is no rule of a general nature, which could be appealed to justify its application. The individual Acts relating to the transport of goods regulate the carrier's liability in a way that is intended to ensure a reasonable balance of the interests of

14 More see e.g. Krzemiński (2010), p. 261 and Hoeks (2010), p. 71.

15 For a different view see Wesołowski (2013), p. 119-120. 
the carrier and the claimant. The interests of the sender or consignee do not override the interest of the carrier. Hence, granting to the claimant the right to free choice of carrier's liability regime would be unjustified. Similarly it is not reasonable to apply the regime of the last stage of carriage. There are no axiological arguments in favour of such a solution.

\section{SUMMARY}

Lack of a comprehensive settlement of a multimodal carriage of goods contract both in international and national law entails the necessity of seeking a proper regime for such a contract. Recognition of the mixed nature of such a contract allows for the use of methods to assess the legal effects of mixed contracts. It helps to establish the regime of the carrier's liability for a non-localized loss. However for parties of a multimodal carriage contract, it is still very difficult to assess its effects at the moment its concludes. Since there is no international instrument concerning a multimodal carriage of goods contract, the proper regulation should be immediately introduced into Polish domestic law. The German solution would be a good pattern to copy.

\section{BIBLIOGRAPHY}

Ambrożuk, D., Dąbrowski, D., Wesołowski, K. (2014). Prawo przewozowe: komentarz. Warszawa: Wolters Kluwer.

Dąbrowski, D. (2015). Przewóz multimodalny w świetle konwencji przewozowych. Przegląd Prawa Handlowego, 11, 30-35.

Glass, D.A. (2013). Freight Forwarding and Multimodal Transport Contracts (2. ed). London: Informa.

Hoeks, M. (2010). Multimodal Transport Law: The Law Applicable to the Multimodal Contract for the Carriage of Goods. Alphen aan den Rijn: Kluwer Law International.

Hoeks, M. (2013). Liability, Jurisdiction and Enforcement Issues in International Road Carriage: CMR Carrier Liability in the Netherlands and Germany and the Influence of the EU. In: Carriage of Goods by Sea, Land and Air : Unimodal and Multimodal Transport in the 21st Century (p. 45-64). Informa Law.

Krzemiński, G. (2010). Pojęcie umowy mieszanej. Studia Prawnicze, 3, 243-269.

Kwaśniewski, Z. (1989). Umowa multimodalnego przewozu towarów w obrocie międzynarodowym. Toruń: Wyd. UMK.

Wesołowski, K. (2013). Umowa międzynarodowego przewozu drogowego towarów na podstawie CMR. Warszawa: Wolters Kluwer.

\section{Odpowiedzialność przewoźnika multimodalnego za szkodę niezlokalizowaną}

STRESZCZENIE $\mid$ Celem artykułu jest określenie właściwego reżimu odpowiedzialności przewoźnika za utratę lub uszkodzenie towaru w sytuacji, w której szkoda nie może być przypisana do konkretnego odcinka przewozu. Autor wskazuje sytuacje, w których reżim odpowiedzialności przewoźnika jest wprost określony przez krajowe lub międzynarodowe prawa przewozowe. Istnieje jednak wiele przypadków, w których odnalezienie właściwego reżimu jest trudniejsze. Autor jest zdania, że umowa przewozu multimodalnego ma charakter mieszany. Przy ustaleniu jej skutków prawnych, w tym reżimu odpowiedzial- 
ności przewoźnika, może być więc pomocne odwołanie się do metod ustalenia skutków prawnych umów mieszanych.

SŁOWA KLUCZOWE przewóz multimodalny, umowa przewozu multimodalnego, szkoda niezlokalizowana, strata niezlokalizowana, odpowiedzialność przewoźnika, umowy mieszane 